\title{
3
}

\section{Tanzanite: Commodity fiction or commodity nightmare?}

\author{
Katherine C. Donahue
}

Rafiki Nderema ${ }^{1}$ leaned back in his chair, finishing off the last piece of goat. A plane landed nearby at the Kilimanjaro International Airport. We were talking about the tanzanite mines not far from the airport. Rafiki is a part-time dealer in tanzanite. 'It can be dangerous,' he said, 'so I hire a woman to take the bus to the mines and pick up the tanzanite. No one knows she is carrying it. Sometimes she changes buses, just to make sure.' When she is confident she is not being followed, she brings the raw gemstones to Arusha, Tanzania, where Rafiki lives, and where tourists usually begin their safaris to nearby national parks or to the Serengeti. Rafiki's wife prepares the tanzanite by cleaning and heating it. A relative helps them with the processing. The treated tanzanite is then marketed.

Tanzanite is available in many shops in Arusha, and it is frequently sold on the streets. Experienced buyers know what to look for, but cost-conscious tourists sometimes end up with lumps of dark glass. The tanzanite gemstone business is just one of several enterprises Rafiki undertakes to support his family. He works in the safari business for himself and for

1 The name is a pseudonym, as is that of a later source. Pseudonyms are used here because the gemstone industry can be dangerous. Hold-ups and shootings still occur in the region. Tanzania is not the only place where gem dealers are robbed; it happens in the US as well. One American jeweller with whom I spoke says that Colombian gangs in particular acquired a specialty in such thefts, staking out jewellery stores for possible marks. 
other companies, as both a driver and a guide. $\mathrm{He}$ is a fine mechanic. He supports not only his wife and children, but also occasionally other family members. His businesses bring him into contact with tourists who may be interested in tanzanite. But to go into business in a bigger way is hard. Credit is difficult to get, and financing large purchases of anything is difficult. His enterprises are all small in scale, but Rafiki gets by. This is a very Tanzanian story.

\section{The problem}

The commodity description of labor, land, and money is entirely fictitious ... Nevertheless, it is with the help of this fiction that the markets for labor, land, and money are organized. (Polanyi 1957: 72)

Karl Polanyi's discussion of the fiction of land, labour and money as commodities was neither the first nor the last analysis of the social meanings attached to things. Things exist in a world of goods (Douglas and Isherwood 1979), they have social lives (Appadurai 1986) and they are circulated and controlled in a web of socio-ecological relations (Donahue 2003). The fictitious nature of commodities, of their supply and of the demand for them, is exemplified in the story of a stone. This chapter discusses the recent commodification of tanzanite, a product sold globally as a semi-precious gemstone. Reported to be '1,000 times more rare than diamonds' (Nones 2005), tanzanite is found solely in one small region of Tanzania, East Africa. Popular with Americans, it has been widely marketed in the US and the Caribbean. Advertisements use the mystique of Mt Kilimanjaro and the Maasai to do so.

However, after 11 September 2001, allegations that al-Qaeda bought tanzanite to finance its operations led to close scrutiny, and almost the collapse, of the tanzanite market. Journalists Robert Block and Daniel Pearl, on the trail of al-Qaeda's financial dealings before 11 September 2001, reported in a November 2001 Wall Street Journal article on the links between al-Qaeda and the tanzanite trade (Block and Pearl 2001). I describe more fully here how the impact of that article, which appeared at the same time that Douglas Farah (2001) of the Washington Post reported on al-Qaeda's connections to the diamond trade in Sierra Leone and Liberia, led to an immediate decline in sales of tanzanite. The adverse publicity concerning 'conflict' or 'blood' diamonds since 2001 (see Farah 2001, 2004a; Campbell 2002), and especially since the 2006 release of the film 
Blood Diamond, has awakened interest in the role of easily transportable and therefore easily smuggled gems in money laundering, in the purchase of weapons and other goods, and in the financing of insurgencies. However, since early 2002, the US and Tanzanian governments have argued that there is no evidence that al-Qaeda is currently involved in the tanzanite trade.

The lure of profit in Tanzania, where the average person currently lives on about US\$920 a year (see World Bank 2014), led to the quick growth of Mererani, the main town near the tanzanite mines, with attendant problems of HIV/AIDS, prostitution and drug use. While the commodification of tanzanite has created profit for gemstone buyers and dealers, and skilful marketing has brought tanzanite to the attention of cruise ship passengers in the Caribbean at the same time that it has been featured as a desirable present for birthing mothers and film stars on the Hollywood red carpet, it has also led to unsafe mining practices, violence over disputed mining rights and pitched battles between smallscale miners and TanzaniteOne, a mining corporation with South African roots. Before the sale of TanzaniteOne to a local Tanzanian company in December 2014, armed security officers for TanzaniteOne patrolled the mining block controlled by this corporation, both above and below ground, in order to keep small-scale miners out. Several miners and a TanzaniteOne employee have died in these disputes. Flash-flooding of mines and faulty air pumps have also led to deaths in Mererani. Tanzanite has thus become both a commodity fiction and a commodity nightmare.

\section{Approaching the field}

Several colleagues at my university and I have taken students to Tanzania to research community-based conservation in two areas of the country. One is on the western slopes of Kilimanjaro, north of Arusha, between the villages of Tinga Tinga and Engare Nairobi. I first encountered tanzanite in the summer of 2002. Students in that year's field course had heard about tanzanite from publicity concerning the 1997 film Titanic. The students were not the only ones who thought the large blue stone, 'The Heart of the Ocean', worn by the actress Kate Winslet, was actually tanzanite. Internet advertisements also featured the connection. Babb (2013) noted that jewellers in Jaipur, India, believed the film was responsible for introducing tanzanite to the global market. 
In January 2004, I visited two stores in Key West, Florida, a cruise ship destination, which prominently advertised the fact that they sold tanzanite. When I inquired, a store employee said that it was one of their fastest selling commodities. Later, back in Tanzania in the summer of 2004, I spoke at some length with a tanzanite dealer, who described the process he went through to buy and prepare it. Subsequently, I have interviewed jewellers in Florida, Massachusetts and New Hampshire in the United States, have read relevant court cases and searched accounts of gemstone commodity production. I attended and wrote about the trial of Zacarias Moussaoui, the so-called 20th hijacker of 9/11 (Donahue 2007), who was also named in a lawsuit connected to tanzanite, and I have pursued the numerous stories of funding sources for al-Qaeda.

What follows here is a discussion of the process by which a stone has become commodified. It has been assigned value despite, or perhaps because of, the fictions that surround this commodity. Other scholars, such as Kelsall (2004), Lange (2006), Schroeder (2010) and Helliesen (2012) have skilfully written about the impact of tanzanite mining, the designation of tanzanite as a conflict gem and on the businesses and people of Tanzania. The violence that attends tanzanite mining has been reported in Tanzanian newspapers (see, for instance, Philemon 2013). Numerous reports have been written about conditions in the mines by researchers for institutions such as the International Labour Organization, the US Department of Labor, United Nations Children's Fund (UNICEF) and the World Bank, some of which are discussed in this chapter. Here, I describe some of the social and political issues that have developed because of the tanzanite industry, but my focus is on the development of the market for tanzanite, the adroit ways in which it has been marketed and the reception of that marketing on the part of buyers in countries such as the US. The emphasis, therefore, is on the downstream ripples created by this particular commodity, ripples that spread to the United States and back to Tanzania. In the first section, I describe the discovery of tanzanite and its subsequent marketing to a worldwide clientele, but in particular to Americans by companies such as Tiffany and TanzaniteOne. Next, I describe the connection between the United States and the tanzanite trade, focusing in part on the allegations that tanzanite was a 'conflict gem'. In the third section, I describe the relationship between the largescale mining company and the small-scale miners, and the conditions in which the miners work. In the fourth section, I explore the role played by local Tanzanians, some wealthy, some not, in attempting to control portions of the tanzanite trade. 


\section{The tanzanite story: Fact or fiction}

Tanzanite had a difficult, dirty and dangerous beginning in the Maasai Steppe of Tanzania. Various stories credit its discovery to at least three people: an Indian tailor, Manuel D'Souza from Arusha, Tanzania; a Maasai cattle herder, Ali Juyawatu; and a Meru cattle herder, Jumanne Ngoma. In July 1967, according to one report, D'Souza was prospecting for rubies in the area east of Arusha when Maasai cattle herders showed him some blue stones. Legend, widely spread on the internet, has it that a lightning strike started a grass fire, as frequently happens in the dry season there. When the fire burned out, some beautifully coloured gemstones were found in the burnt grass. The stones were a rare form of zoisite, a calcium aluminum silicate. The semi-precious gemstone in its natural state is often a rather uninteresting purple/brown in colour. But when this particular form of zoisite is heated to 300-500 degrees centigrade, it turns a sapphire blue, or purple or red. In the gem trade, this trait is referred to as 'trichroic', as having three colours when the stone is turned to the light. To date, this form of zoisite is found only in the Manyara region, Simanjiro district of Tanzania. The mining area is in the Mererani hills southeast of Arusha, not far from the Kilimanjaro airport, and north of the Simanjiro plain. The Maasai people, primarily cattle herders, have lived there since their migration south from Kenya hundreds of years ago. Some have become brokers for tanzanite, but the miners themselves often come from elsewhere in Tanzania, leaving behind their own poverty to engage in more poverty, to dig and crawl through the more than 300 pit mines and accompanying tunnels to depths of 500 $\mathrm{m}$. Some miners work 18 -hour shifts. Some miners were reportedly only seven years old. Drugs, alcohol, sex, HIV/AIDS and crime are commonly reported there. In 2004, Daniel Yona, the minister of energy and minerals, declared during a visit to Mererani that 60 per cent of the inhabitants had HIV/AIDS (Arusha Times 2004a). This was most likely an exaggeration, however unwitting, but the figure did indicate the social perceptions of the area.

When buyers from Tiffany, the upscale New York-based jewellery company, first saw the stones in the 1960s, their interest was aroused. It was Henry B. Platt of Tiffany who reportedly gave the name 'tanzanite' to the stones, and who said that the discovery of the gemstone was 'the most exciting event of the century' (Time 1969). Another statement from Tiffany said that tanzanite was 'the most beautiful blue stone to be discovered in 2,000 years' (Tanzanite Foundation n.d.). Although the 
market did not expand through the 1970s, its popularity grew during the 1980s through good advertising. By the time of the release of the film Titanic in 1997, interest in tanzanite had expanded to the point that jewellery stores in the Caribbean, in Florida and even in Alaska had difficulty keeping it in stock. Not unlike the techniques used in marketing diamonds, tanzanite had acquired its own mystique and legend. 'From the foothills of Mt. Kilimanjaro', said the internet marketers on one website. 'Unlocking the riches of Mt. Kilimanjaro', said another (Nones 2005). One website claimed that the Maasai give tanzanite to women who have just borne a child. It displayed a photo of a Maasai woman wearing a tanzanite stone. While it is the case that many Maasai women wear blue clothing, some websites, such as that for Tanzanite Gallery (2007), a gem dealer, stated:

Recent Maasai tradition tells of how pieces of tanzanite were given by Maasai Chiefs to their wives on the birth of a baby to bestow upon the child a healthy, safe and positive life. According to their customs, only women who have been blessed with the miracle of new life have the honour of wearing blue coloured beads and garbs.

In this vein, the Tanzanite Foundation, a non-profit group established by the TanzaniteOne mining company, was created. The website for the Tanzanite Foundation once stated that it:

strives to develop the tanzanite industry by growing demand and creating value for stakeholders in the tanzanite value chain. By striving to standardize methods of practice and conduct, the Tanzanite Foundation aims to uphold an ethical route to market in accordance with the Tanzanite Tucson Protocols, and invests in meaningful and sustainable upliftment projects developed in harmony with the indigenous communities in Tanzania. (TanzaniteOne 2007)

The foundation, run by a public relations firm, launched a tanzanite marketing campaign in 2006 specifically aimed at the 'Push Present' market, meaning the market for presents to women who have just pushed through labour (Colored Stone 2005). According to one online dictionary, Karen Heller in the Austin American-Statesman on 31 March 1992 wrote of the Oscars:

Let us say that Annette Bening has lost all that baby weight-Warren must have given her a ThighMaster as a push present—and looked understated yet ravishing. (Double-Tongued Dictionary 2007) 
The website for the Tanzanite Foundation included in its image gallery a photo of a Maasai woman wearing blue, with a baby on her back and a large tanzanite necklace around her neck, hanging just above the baby's head (TanzaniteOne 2008). By 2007, the foundation had created awards for the designers of jewellery made as part of their 'Be Born to Tanzanite' campaign. They did move beyond marketing to build two schools, an orphanage, a clinic and the Maasai Ladies' Project, teaching Maasai women how to use wire to make jewellery using discarded tanzanite, and serving as an advocacy group overall. However, because of unrest in Mererani, by August 2014 the Tanzanite Foundation had closed its operations, as did TanzaniteOne.

\section{An American story: The market for tanzanite}

The market for tanzanite in the United States and Caribbean is a particularly American story. In the 1990s, it was something new and still somewhat affordable for Americans, and was considered a good investment if you knew what you were looking for. The production and marketing of tanzanite became problematic once reports surfaced that tanzanite was bought and smuggled out of Tanzania by al-Qaeda members. After the attacks of 11 September 2001, Robert Block and Daniel Pearl of the Wall Street Journal investigated the trade in tanzanite at its source; their report brought a halt to the importation of tanzanite to the United States. The US State Department, the Tanzanian Government and the gem industry reached an accord in February 2002-the 'Tucson Tanzanite Protocol' - that reopened imports to the US. After that, the market for tanzanite became steadier, but the production at the source became less so. Schroeder (2010) has described the impact of the move toward ensuring ethical mining practices on the Tanzanian Government and the stakeholders in the tanzanite mining industry. The argument has been made that disputes between small-scale miners and AFGEM (African Gem Resources)/TanzaniteOne, as well as poor infrastructure and low foreign direct investment have caused a drop in production. The American and Tanzanian governments worked to take steps toward the regularisation and control of the export of tanzanite, steps mirrored in other mining and export sectors, and new marketing strategies such as those by TanzaniteOne to support interest in the stone. Thus, the future of small-scale and large-scale miners of tanzanite was linked to American politics and concerns about terrorist acts on American soil. 


\section{The al-Qaeda connection}

On 16 November 2001, Robert Block and Daniel Pearl's piece ('Underground Trade: Much-Smuggled Gem Called Tanzanite Helps Bin Laden Supporters') on al-Qaeda's involvement in buying and smuggling tanzanite appeared in the Wall Street Journal (Block and Pearl 2001). After the bombings of the US embassies in Kenya and Tanzania in 1998, and particularly after 11 September 2001, the United States searched for any sources of money that might support al-Qaeda, and proceeded to shut down a number of banks and aid associations. Al-Qaeda apparently sought out other means of moving money after 1998, including buying diamonds in Liberia and Sierra Leone (see Farah 2001, 2004a, 2004b; Campbell 2002). Block and Pearl reported that al-Qaeda members were also buying tanzanite in Tanzania, which the buyers then smuggled out of Tanzania into Kenya, and thence to buyers in Dubai and elsewhere. Block and Pearl identified an imam of a mosque in Mererani who was sympathetic to Osama bin Laden, and a tanzanite dealer who worked with that imam. Daniel Pearl was murdered in Pakistan in January 2002, while still on the trail of al-Qaeda's finances for the Wall Street Journal. As a result of Block and Pearl's article and other news stories, large gem retailers such as QVC, Birks, Peoples, WalMart, Zale Corp. and Tiffany \& Co. all stopped selling tanzanite, much to the concern of the Tanzanian authorities, for whom the US market for tanzanite represented the majority of its exports of that gemstone (Roskin 2002; Hübschle 2004). The US State Department investigated, and said it found little evidence connecting al-Qaeda with tanzanite. By 9 February 2002, the Tucson Tanzanite Protocols were announced in Tucson, Arizona, which is a major centre for the global gem industry. Edgar Maokola Majogo, the Tanzanian Minister of Energy and Minerals, representatives of international gem dealers' associations and Michael O'Keefe of the US State Department Office of East African Affairs were all present. The Tucson Tanzanite Protocols stated that the Government of Tanzania 'has taken and continues to take significant steps to safeguard this gemstone' by licensing miners and traders in Tanzania, and ensuring for all countries 'transparency and accountability in the supply chain'. Furthermore, warranties were to be required of exporters and 'all those in the downstream chain of commerce' (Tanzanite Gems 2002).

As a result of the reported links between al-Qaeda and tanzanite, a lawsuit was filed in the federal district court in New York City. In February 2002, lawyers for families of three victims of the 11 September terrorist attacks filed a wrongful death suit against STS Jewels, Inc., owned by 
Sunil Agrawal, a tanzanite dealer, and the Tanzanite Mineral Dealers' Association (TAMIDA). The plaintiffs wanted an injunction banning STS Jewels from selling tanzanite and:

forcing it to contribute all proceeds from any past tanzanite sales to a courtsupervised 9/11 victims' relief fund. The suit also sought $\$ 1$ billion in compensatory damages from other defendants, which included not only TAMIDA but also Osama bin Laden, the former Taliban government of Afghanistan, the Iraqi government, and the supposed '20th hijacker' of 9/11, Zacarias Moussaoui. (Tanzanite Gems 2002)

The suit was withdrawn with prejudice on 8 April 2002, meaning that the case could not be brought again. According to Sunil Agrawal, the head of STS Jewels: 'To a potential plaintiff, the lawsuit's withdrawal sends the message: there's nothing there ... I feel vindicated' (Tanzanite Gems 2002; see also Markon 2002).

In March 2002, after the Tucson Protocols were announced, Tanzanian Minister Majogo accused AFGEM, the South African tanzanite mining company, of inviting Robert Block of the Wall Street Journal to Arusha and Mererani to write about the tanzanite trade. Minister Majogo accused AFGEM of intending to make it difficult for the local Tanzanian miners to sell their unbranded, undocumented gems on the market. AFGEM was at the time preparing to ensure that each gemstone sold from their mine was to be identified and guaranteed, and they reported that the controls they were initiating were designed to bring order to the tanzanite industry (Beard and Kondo 2002; Kondo 2002).

By early 2002, questions had been raised as to the veracity of Block and Pearl's article. According to one source, the imam of the mosque described by them was incorrectly identified. Other names and facts were said to be inaccurate, and the people identified in the article denied their sympathies with Osama bin Laden's cause (see, for example, Maharaj 2002; Hübschle 2004). Annette Hübschle, in a report on crime in southern Africa, suggested that Block and Pearl's article was a case in which 'journalists in need of a good news story may have blown an allegation out of proportion' (Hübschle 2004: 9). Michael O'Keefe of the US State Department, who was present at the announcement of the Tucson Tanzanite Protocol, said:

I think they looked at the trade ... saw it was chaotic, not totally controlled, with a certain percentage lost to smuggling, and they tied that to al-Qaeda ... [But] our resources are a hell of a lot bigger; we have an intelligence community. (Beard and Kondo 2002) 
The gem dealers were happy. By September 2002, the Jewellers' Circular Keystone reported that:

U.S. State Department representative Michael O'Keefe has repeatedly told the jewelry industry that there is no evidence that any terrorist organization is funding operations through the sale of tanzanite. (Roskin 2002)

Tiffany began to sell tanzanite jewellery again in June 2002, saying that:

Based on lack of credible evidence linking tanzanite and terrorism as well as progress to further controls over trade in tanzanite, Tiffany \& Co. has resumed the sale of jewelry containing this gemstone. (Roskin 2002)

Furthermore, the American Gem Trade Association announced in October 2002 that tanzanite was to become a December birthstone, along with turquoise and zircon. Although other stones had been added to the list, news reports circulated that tanzanite became the first gemstone to be added to the birthstone list since 1912 (Weldon 2002). The demand side of the tanzanite story became healthy again.

A jeweller from St Maarten in the Caribbean said, 'In the 1980s no one had heard of tanzanite. Three years ago (1999) everyone started to carry it' (Roberts 2002). Tourists in the Caribbean are now well versed in tanzanite. As one couple's website said:

Do we look like tourists? We're guessing Key West has seen a tourist or two in her day. We did a lot of shopping and returned to the ship loaded down with key lime souvenirs (and a little birthday tanzanite). (Bundy and Schilling 2002)

According to many reports, 80 per cent of all tanzanite has gone to buyers in the United States (see Roskin 2002; Hübschle 2004). Most of the rest of it goes to the Caribbean. There, it is bought by cruise ship passengers, many of whom are North Americans. Diamonds International began doing business in 1986 in St Thomas, and now has over 100 stores in the Caribbean, Florida, Mexico, Las Vegas and Alaska. Seizing on the interest in tanzanite, Diamonds International created a separate chain of shops, Tanzanite International. There are several competitors selling tanzanite on Duval, the main shopping street in Key West. Some jewellery stores post large signs outside the shop advertising the sale of tanzanite. One such is the Jewel Port, which, on its signs and on the internet, claimed it had the 'Best Collection of Tanzanite, (10\%-70\% off select items)'. One jeweller there told me in 2004 that tanzanite was the gemstone most cruise ship 
passengers were interested in buying. Some of those passengers become informal experts on tanzanite. One former cruise ship passenger wrote in the following about a 2003 cruise:

Day 5: Grand Cayman

Just behind Columbian Emeralds there are a number of shops situated around a courtyard. For those interested in Cigars, there is a very nice shop located in this area, as well as a shop called Island Pleasures. This is also a jewelry store but they sell a lot of loose Tanzanite. Normally Tanzanite can sell for up to $\$ 700$ a carat but I was able to but [sic] a pair of 2 (identical in color and shape $-1 \frac{1}{2}$ carats total) for $\$ 299.00$. Loose stones also do not have to be declared on your Customs forms. After some other souvenier [sic] shopping we went back to the ship. (McClure 2003)

In November 2005, one cruise ship passenger, 'Irish Boy', posted the following query to fellow readers of a cruise ship message board:

\section{Hi Gang}

Just got off the Victory \& Imagination in October and if I ever hear the word Tanzanite again I will jump off the nearest bridge ... what is this stuff I never heard of it before but never heard so much about it for 7 days on the cruise, do the cruise lines own a mine or what ... observations please. : confused. (Irish Boy 2005)

A travel writer observed that tanzanite had become so popular with the cruise ship industry that it appeared as the only gemstone listed in a glossary of nautical terms, along with 'port' and 'starboard' (Clausing 2008). She went on to say that:

Tanzanite is a beautiful blue or purple stone seemingly found only in two places in the world: Tanzania, and cruise ships. You may find it in shops at home, but it seems to be a particular obsession in cruising circleson some sailings you can't swing a shuffleboard cue without hitting a boutique specializing in the stone.

Even in Ketchikan and Skagway, Alaska, cruise ship passengers are briefed by 'port lecturers' on tanzanite acquisition at local gem stores. In turn, the stores are expected to pay the cruise lines a certain percentage of their profits (Glass 2012). One jeweller said he had paid US\$25,000 and was expected to give 10 per cent of his earnings to the cruise shopping programs in addition. Complaints from customers and local businesses came to the attention of the consumer protection authorities for the state 
of Alaska; in 2013, the state of Alaska moved to require port lecturers to reveal the fact that they are advertising for these jewellery companies (Gutierrez 2013).

In October 2005, rings at one store in New Hampshire in the US were retailing at US\$139 for tanzanite set with diamonds; a bracelet of tanzanite and diamonds was US\$399. By January 2007, the same store was selling a tanzanite ring set with diamonds for US\$799, and a bracelet of tanzanite and diamonds cost US $\$ 1,400$, while anzanite pendants were selling for US\$200-300. By January 2008, earrings and pendants were selling for US $\$ 400$ each, while a set containing a ring, earrings, and a pendant was US\$199. Demand had declined by 2008, a salesperson said, because tanzanite was not marketed as widely, and it was less available. Another jeweller in New Hampshire said he usually bought his tanzanite from a gem dealer in Boston, Massachusetts, but that dealer now spends more time buying sapphires in Sri Lanka than tanzanite in Arusha, Tanzania.

A carat is one-fifth of a gram. According to one jeweller in Massachusetts, cut tanzanite sells for between US $\$ 500$ and US\$3,000 a carat (2016 prices), depending on the cut, clarity and the quality of the stone. Cut diamonds can sell for US\$5,500-6,000 a carat. Tanzanite occurs naturally in a variety of sizes and it often requires preparation by cutting and polishing. I have seen an unpolished and uncut 20-carat stone, valued at US\$2,300, and a photo of a smaller cut tanzanite that was sold for US $\$ 8,000$. It should be noted that the terms 'precious' and 'semi-precious' for gemstones are used less frequently now than in the past. For instance, a good-quality semiprecious tourmaline is usually more expensive than a lesser-quality diamond.

The global downturn in the economy after 2008 has had an effect on commodity production. One example is provided by Tiffany, the New York jeweller. When Wall Street provided end-of-year bonuses, Tiffany's Wall Street store was visibly advertising its wares. Holiday sales were an important source of income, but soft sales in 2009, as well as, for example, in 2015, led Tiffany to reduce its staff (Beilfuss 2016). Tanzanite International and its parent company, Diamonds International, continue to serve the cruise ship trade in the Caribbean and Alaska, but the standalone Tanzanite International store in Key West, Florida, eventually closed. Jewellery store owners, with whom I talked between 2009 and 2015, 
reported that they do not get as many requests for tanzanite as formerly, and order it only as needed. Three jewellery stores each had only five or six small stones on hand.

\section{Mining in Mererani}

To allow the market mechanism to be sole director of the fate of human beings and their natural environment, indeed, even of the amount and use of purchasing power, would result in the demolition of society. (Polanyi 1957: 73)

The mines at Mererani were nationalised by the Tanzanian Government in 1971, and the State Mining Corporation, or STAMICO, took over production. This occurred during President Julius Nyerere's period of Ujamaa, Tanzania's version of socialism. Despite his and the program's best intentions, nationalisation failed to produce economic development. The movement's efforts to avoid the social injustices of free markets in the West were a test of an economic system that did not have the support of an infrastructure, both national and international, to keep it going. State mining efforts and production declined steadily at Mererani, while smallscale mining increased rapidly.

By 1990, the Tanzanian Government tried to increase control over the smallscale miners, and divided the area into four blocks. Block A was licensed by Kilimanjaro Mines Ltd, Blocks B and D were reserved for small-scale miners and Block $\mathrm{C}$ was taken by Graphtan Limited, a graphite mining company. Graphtan ceased production in 1996, and AFGEM acquired the licence. According to the TanzaniteOne website, AFGEM began tanzanite production in 2001. TanzaniteOne, based in Bermuda but with directors also associated with AFGEM, took over control of Block C in 2004.

Disputes arose when the small-scale miners expanded tunnels out and under other blocks, in particular into Block C, the AFGEM/ TanzaniteOne block (Hernandez 2003: 10). In 2001, conflict erupted between small-scale miners and AFGEM. Gunfire was exchanged between AFGEM guards and miners in April that year, and an AFGEM building was bombed during Easter weekend (Ngowi 2001: 32). By March 2002, the Tanzanian mining minister had accused AFGEM of inviting the Wall Street Journal reporters to Mererani to investigate the al-Qaeda connection. AFGEM sought good public relations by providing water to 
Maasai people and cattle during a December 2003 drought (Arusha Times 2003). In December 2006, the Manyara regional police commander gave TanzaniteOne, AFGEM's successor, the authority to use 'reasonable force' to protect its mining concession from artisanal miners, particularly those who tunnel underground into Block C. 'Reasonable force' included the use of air guns and live bullets. This action, the police commander said, was necessary because the small-scale miners used explosives underground, not only to frighten the TanzaniteOne security guards, but also to blow off grills that were placed to keep out the small-scale miners (Ihucha 2006).

Small-scale mining operations, while apparently chaotic, appear to be increasingly self-regulating. Bryceson et al. (2013) argue that smallscale miners have provided a democratising force in countries that are becoming increasingly 'mineralised' - that is, reliant on mining for economic improvement as traditional agriculture becomes less dependable as a source of income. The government has not acquired much control over operations. As miners arrived to try their luck, they began to register and licence themselves through informal and formal mining associations. According to Hernandez (2003), rights to plots of lands that were $25 \mathrm{~m}$ x $25 \mathrm{~m}$ have been given out to these miners. More recently, the smallscale miners have pushed the government to impose restrictions on export of unprocessed tanzanite in order to provide more jobs for Tanzanian processors. In a hearing in Mererani in January 2008, representatives of the miners asked for in-country annual auctions to ensure that international gemstone buyers would leave their money in Tanzania and, presumably, not deal with sources in India or elsewhere (Juma 2008).

\section{Social and environmental issues in tanzanite production}

[T] he alleged commodity 'labor power' cannot be shoved about, used indiscriminately, or even left unused, without affecting also the human individual who happens to be the bearer of this peculiar commodity. (Polanyi 1957: 73)

Tanzanite mining, as with mining elsewhere, relies on the labour of the young and agile. Predominantly male, these young people have left subsistence agriculture behind, hoping to find gems. Small-scale mining occupies approximately half a million Tanzanians (Kinabo 2003) or more. Eftimie et al. (2012) reported that there were 550,000 small-scale 
miners in Tanzania, of whom 25 per cent were women. According to a miner, Mzee Nyumbani (a pseudonym), and others, there is substantial migration of young Arusha, Meru and Pare to the area of the tanzanite mines (Sheridan 2005). Some become farmers, growing maize and beans, while others work in the mines. The urban area of Mererani has grown from 37,109 people in 2002, according to the Tanzanian Housing and Population Census (United Republic of Tanzania 2002) to 50,800 in 2012 (Tageo.com 2012). A report on the Tanzanian mining sector said that 79 per cent of inhabitants of Mererani were people who moved in between 1985 and 1995 from other regions of Tanzania; those surveyed had earlier been farmers and civil servants (Mwalyosi 2004: 12).

For some Tanzanians, the system works to their benefit. Kelsall (2004: 47) describes Asfoku Mollel, a Maasai who entered the mining trade early and now owns several pits, reportedly worth hundreds of millions of Tanzanian shillings (as of early 2016, TZ2,100 = US\$1). Mollel has invested in an hotel, a bus company, a football team and real estate.

Mzee Nyumbani described his own experiences as a Pare miner to Michael Sheridan, an anthropologist, as follows:

In 1978, I started to dig for these gemstones [tourmaline?]. I was able to build a house in the town of Landanai, and I was able to buy first one vehicle then another. I continued to mine until I reached where I am today, now I have 15 vehicles and 32 houses. This kind of success from gemstones is what draws many youths from all over Tanzania, and this is indeed the reason why Pare agriculture is left to old people ... Many youths who mine don't need much skill because it is their strength that is important. (Sheridan 2005)

Nyumbani went on to say that after the Europeans left, their equipment stopped working properly, increasing the need for physical labour. 'There in the bush near Arusha now there are about 20,000 people who are mining for gemstones every day' (ibid.).

According to Groves (2000), 11 per cent of the young miners in Mererani had not been to school and 75 per cent were under 16, the legal age for mining in Tanzania. A 2003 South African report placed the number of child labourers in Mererani at 22,500 (Kinabo 2003). Many of these children do not actually work in the mines but are hired to bring water and food to the miners, or, according to this report, to spy on the miners 
to ensure the miners will not steal the gemstones. Child miners, some as young as seven, are reported to number between 2,800 and 3,200 (ibid.: 48).

An International Labour Organization report (ILO 2003) on international child labour issues profiled a young former miner, Hamisi, who spoke of his time in the mines:

I nearly suffocated inside the pits due to an inadequate supply of oxygen ... At the mining sites and in the township we were called 'nyokas,' or 'snake boys,' since we literally crawled along the small tunnels underground just like snakes.

He said he often worked up to 18 hours a day with only one meal of buns and boiled or cooked cassava. According to the report:

Children who work under the supervision of pit owners at the Mererani mines are paid around US\$ $0.60-1.20$ when they are assigned some tasks. Some children try their luck sorting the gravel left over by pit owners and can make considerably more on the extremely rare occasions that they find a gemstone. Their earnings in such cases may range from US\$ 24.57-122.60.

Gem Slaves: Tanzanite's Child Labour, a short film made by the UN Office for the Coordination of Humanitarian Affairs, was released in 2006. The film stated that 4,000 child miners worked in the mines every day (IRIN News 2006b). The film was quickly criticised by some Tanzanians, and by TanzaniteOne, for the figures used for child labour (Newman 2007).

In 2011, the TanzaniteOne mining company donated TZ3 million to an orphanage that had brought child miners back to school (Arusha Times 2011). The director of the orphanage at the time was Dorah Mushi, a former member of parliament and one of the founders of the Tanzanite Women Miners Development Association in 2004.

Conditions in the mines are difficult for those of any age. In April 1998, rainwater flooded the mines and more than 50-some sources later reported up to 200-miners died (BBC 1998). On 22 June 2002, the $\mathrm{BBC}$ reported that as many as 42 miners had died in the tanzanite mines. This time, a fresh air pump had failed. Following the air pump tragedy, the Tanzanian Government temporarily halted all mining activities at Mererani (BBC 2002). Things were not much improved when miners returned. In April 2004, the Arusha Times reported that on 19 April two 
young men were found dead in an unused mine in Block B. They had never been employed by the owner, according to the paper, and the police thought that they had probably suffocated because of lack of air in the tunnel (Arusha Times 2004b).

There continue to be other environmental consequences as well. Those who have money in Mererani can afford to buy bush meat, reported by the Arusha Times to come from poached animals, some of whom are killed when they move across Arusha National Park boundaries. Zebra, bushbuck, giraffe and buffalo meat have all been confiscated or found at markets both in Mererani and in Sanya Juu, a town to the north (Nakora 2004).

Bråtveit et al. (2003) reported in the Annals of Occupational Hygiene that exposure to dust in Mererani's 300 privately owned mines was high. The 15,000 miners, working occasionally at a depth of $500 \mathrm{~m}$, are usually without protection. Small-scale miners are at high risk for chronic silicosis, with 'total' dust at a median level of $28.4 \mathrm{mg} / \mathrm{m}^{3}$ (Bråtveit et al. 2003: 235). Given these conditions, it is no wonder that the miners engage in risky behaviour. The Arusha Times in July 2003 (Nyaumame 2003) reported that the:

Simanjiro District Commissioner, Mr. Fillemon Shelutete said the town's residents are noted for smoking bhang, chewing khat and drinking the illicit liquor popularly known as 'gongo'.

To make conditions somewhat more difficult, Mererani, as with many mining towns, has a larger number of males compared to females. A Tanzanian census found that by 2002 there were 21,000 males and 16,000 females in the region (United Republic of Tanzania 2002). Given the spread of HIV/AIDS, the health workers were concerned-a 2012 UNICEF report indicated that 1.5 million Tanzanians (of a total population of 48 million), or 3 per cent, were HIV positive. For adults aged 15-49, the number was 5.1 per cent. In the Mererani area, the figure may be substantially higher. On 1 June 2004, Daniel Yona, the minister of energy and minerals, opened a four-day workshop for the small-scale miners of Mererani. He was quoted as saying that 60 per cent of all inhabitants of Mererani were HIV positive, and that there were at least 500 female sex workers in the town (Arusha Times 2004a). In 2005, the prime minister at the time, Edward Lowassa, said Mererani had a HIV prevalence rate of 16.4 per cent, in comparison to the national average of 7 per cent of all adults (IRIN News 2006a). The 60 per cent figure was most likely misheard in place of the 16 per cent cited by the prime minister, but there is no way to confirm it at present. 
Missionaries have increasingly spent time in Mererani, establishing schools and bringing in health clinics to help with the problem (see Rothery and Rothery 2004). In 2004, women formed the Tanzanite Women Miners Development Association, or TWMDU; in 2005, women were finally allowed to enter the mines (Kondo 2005). They now have a strong voice in discussing conditions at the mines. There is also now a dispute committee in Mererani, which attempts to mediate conflicts between miners (ibid.). In March 2015, Jumanne Ngoma, the Meru cattle herder who had said he was the first to find tanzanite, was awarded the Order of the United Republic, second class, by President Jakaya Kikwete (Mwakyusa 2015). In what could be called a victory for local Tanzanians, on 26 November 2014, Richland Resources announced the conditional sale of its Tanzanian mining operations to Sky Associates Group Limited, an Arusha company. Richland said it planned to focus on developing the Capricorn Sapphire mine in Queensland, Australia. Then, on 2 February 2015, Richland Resources reported it was shutting down its Tanzanite Experience retail operations in Tanzania (Interactive Investor 2015). In April 2015, the Arusha store and museum was reopened, featuring a full-scale tanzanite mining shaft. According to their website, its goal is to educate tourists about tanzanite mining, and they sell certified tanzanite there and at another location in Arusha and in Ngorogoro (Philemon 2015). In the summer of 2015, Minister of Energy and Minerals George Simbachawene announced an initiative to conserve Mererani itself as a tourism destination (The Guardian/ IPP Media 2015). On the face of it, tanzanite looked as though it could have been profitable. Ihucha (2016) reported that export revenues were US\$38 million, and worldwide revenues were US\$500 million a year. But, in January 2016, TanzaniteOne, now controlled by Sky Associates of Arusha, laid off half of its workers. Citing reduced production of tanzanite (50 per cent during fall 2015), and expenses in buying mining equipment and pay, they let go 618 out of over 1,200 workers. One of the directors also said that increased illegal mining had led to this decision (Brummer 2016). In a way, the small-scale miners had won.

\section{Conclusion}

The complicated fictional web of land, labour and money that has been spun around tanzanite is similar to that woven around other commodities. Diamonds, rubies, lumber, water, air, manmade objects, natural objects and knowledge are all caught in the webs of human significance that 
humans have created, and from which humans find it difficult to extricate themselves. There remain unanswered questions concerning tanzanite: Why was the US State Department so dismissive of the connection to al-Qaeda made by Block and Pearl? What will become of the small-scale miners if the Tanzanian Government does indeed gain control over the mining operations and the cutting and export of stones? What will happen when the supply of tanzanite runs out? Tanzanian resilience and entrepreneurial ability keeps these people afloat. It will take a combination of local control, government monies and continuing investment to make the situation easier for the inhabitants of Mererani, and for those who wish to join them.

As Polanyi (1957: 73) has said:

Robbed of the protective covering of cultural institutions, human beings would perish from the effects of social exposure; they would die as the victims of acute social dislocation through vice, perversion, crime, and starvation ... But no society could stand the effects of such a system of crude fictions even for the shortest stretch of time unless its human and natural substance as well as its business organization was protected against the ravages of this satanic mill.

\section{Acknowledgements}

I thank Michael Sheridan, Paul Gross, Gideon Njenga and others in Tanzania for their various roles in thinking through the complexities of the commodification of tanzanite and of life in Tanzania. Krisan Evenson of Plymouth State University helped with the complexities of words.

\section{References}

Appadurai, A. (ed.), 1986. The Social Life of Things: Commodities in Cultural Perspective. Cambridge: Cambridge University Press. doi. org/10.1017/CBO9780511819582

Arusha Times, 2003. 'Water Almost as Rare as Tanzanite.' No. 299, 6-12

December. Viewed at www.arushatimes.co.tz/2003/48/local_news _5.htm (site discontinued) 
Arusha Times, 2004a. 'Mererani Suffers Ravages of AIDS.' No. 323, 5-11 June. Viewed at www.arushatimes.co.tz/2004/22/front_page_1.htm (site discontinued)

Arusha Times, 2004b. 'Two Found Dead in Mererani Quarry.' No. 317, 24-30 April. Viewed at www.arushatimes.co.tz/2004/16/front_page _3.htm (site discontinued)

Arusha Times, 2011. 'Tanzanite-One Employees Assist Mererani's GoodHope Orphanage.' 30 April - 6 May. Viewed at www.arushatimes. co.tz/2011/16/Local\%20News_2.htm (site discontinued)

Babb, L.A., 2013. Emerald City: The Birth and Evolution of an Indian Gemstone Industry. Albany, NY: State University of New York Press.

BBC, 1998. 'Over 50 Dead in Tanzanian Mining Disaster.' BBC News, 14 April. Available at news.bbc.co.uk/2/hi/africa/77864.stm

BBC, 2002. 'Tanzania suspends gem mining.' BBC News, 22 June. Available at news.bbc.co.uk/1/hi/world/africa/2059985.stm

Beard, M. and H. Kondo, 2002. 'Industry Introduces Tanzanite Tracking.' Colored Stone. March/April. Viewed at www.tucsonshowguide.com/ stories/mar02/tanzanite.cfm (site discontinued)

Beilfuss, L., 2016. 'Tiffany Cuts Guidance and Staff after Weak Holiday.' Available at www.marketwatch.com/story/tiffany-cuts-guidance-andstaff-after-weak-holiday-2016-01-19

Block, R. and D. Pearl, 2001. 'Underground Trade: Much-Smuggled Gem Called Tanzanite Helps Bin Laden Supporters.' The Wall Street Journal, 16 November, p. A1.

Bråtveit, M., B.E. Moen, Y.J.S. Mashalla and H. Maalim, 2003. 'Dust Exposure during Small-Scale Mining in Tanzania: A Pilot Study.' Annals of Occupational Hygiene 47: 235-40.

Brummer, D. 2016. 'Tanzanite Miner Sheds 600 Jobs.' IDEX, 25 January. Available at www.idexonline.com/FullArticle?Id=41562

Bryceson, D., E. Fisher, J. Jønsson and R. Maipopo (eds), 2013. Mining and Social Transformation in Africa: Mineralizing and Democratizing Trends in Artisanal Production. London: Routledge. 
Bundy, T. and D. Schilling, 2002. 'Day 7, Key West, Caribbean Cruise.' Available at www.bundlings.com/caribbean07.htm

Campbell, G., 2002. Blood Diamonds: Tracing the Deadly Path of the World's Most Precious Stones. Boulder: Westview Press.

Clausing, N., 2008. 'Don't Call it a Boat: Cruise Ship Vocab 101.' Travelocity. Viewed at leisure.travelocity.com/DestGuides/ (site discontinued)

Colored Stone, 2005. 'TanzaniteOne Launches New Supply Strategy.' January/February. Viewed at www.colored-stone.com/stories/jan05/ tanzaniteone.cfm (site discontinued)

Donahue, K.C., 2003. 'Conceptualizing Social Ecology: The Logics of an Anthropological Practice.' Paper presented at the XV International Congress of the Anthropological and Ethnological Sciences, Florence, Italy, 5-12 July.

Donahue, K.C., 2007. Slave of Allah: Zacarias Moussaoui vs. The USA. London: Pluto Press.

Double-Tongued Dictionary, 2007. 'Push Present.' Available at www. doubletongued.org/index.php/dictionary/push_present/

Douglas, M. and B. Isherwood, 1979. The World of Goods. New York: Basic Books.

Eftimie, A., K. Heller, J. Strongman, J. Hinton, K. Lahiri-Dutt, N. Mutemeri, C. Insouvanh, M. Godet Sambo and S. Wagner, 2012. Gender Dimensions of Artisanal and Small-Scale Mining: A Rapid Assessment Tool. Washington, DC: World Bank Group's Oil, Gas and Mining Unit. Available at siteresources.worldbank.org/ INTEXTINDWOM/Resources/Gender_and_ASM_Toolkit.pdf

Farah, D., 2001. 'Al Qaeda Cash Tied to Diamond Trade. Sale of Gems From Sierra Leone Rebels Raised Millions, Sources Say.' The Washington Post, 2 November, p. A1.

Farah, D., 2004a. Blood from Stones: The Secret Financial Network of Terror. New York: Broadway Books. 
Farah, D., 2004b. 'The Role of Conflict Diamonds in Al Qaeda's Financial Structure.' Social Science Research Council, Global Security and Cooperation. Viewed at www.ssrc.org/programs/gsc/gsc_activities/ farah.page (site discontinued)

Glass, N., 2012. 'Cruise Ships Financially Exploit Onshore Stores.' The Blog, Huffington Post, 21 May. Available at www.huffingtonpost. com/nicole-glass/cruise-ships-financially-_b_1531590.html

Groves, L., 2000. 'Child Miners in Mererani, Tanzania: An Anthropological Perspective.' Mimeo, University of Edinburgh.

Gutierrez, A. 2013. 'Alaska Tries to Curb Cruise Ship Kickbacks.' Alaska Public Media, 22 August. Available at www.alaskapublic. org/2013/08/22/alaska-tries-to-curb-cruise-ship-kickbacks/

Helliesen, M.S., 2012. 'Tangled Up in Blue: Tanzanite Mining and Conflict in Mererani, Tanzania.' Critical African Studies 4(7): 58-93. doi.org/10.1080/21681392.2012.10597799

Hernandez, A., 2003. 'Mining Cadastre in Tanzania.' FIG Working Week 2003, Paris, France, 13-17 April.

Hübschle, A., 2004. 'Unholy Alliance? Assessing the Links Between Organized Criminals and Terrorists in Southern Africa.' ISS Paper 93, Institute for Security Studies.

Human, R., 2006. 'Tanzanite Trouble.' The New Internationalist, Issue 388: 22-23.

Ihucha, A., 2006. 'Govt Allows TanzanineOne (sic) to use Live Bullets on Intruders.' IPP Media, 30 December. Viewed at www.ippmedia.com/ ipp/guardian/2006/12/30/81343.html (site discontinued)

Ihucha, A., 2016. 'Gemstone Firms Sheds 600 Jobs to Cut Costs.' The Citizen, 11 January. Available at www.thecitizen.co.tz/News/ Business/Gemstone-firm-sheds-600-jobs-to-cut-costs/-/1840414/ 3028766/-/5cbwjdz/-/index.html

Interactive Investor, 2015. 'Richland Resources.' Interactive Investor, 2 February. Available at www.iii.co.uk/research/LSE:RLD/news/ item/1368139/closing-tanzanite-experience-retail-operations 
International Labour Organization (ILO), 2003. 'Child Labour Stories, Hamisi.' Available at www.ilo.org/wcmsp5/groups/public/---ed_norm /---declaration/documents/publication/wcms_decl_fs_44_en.pdf

IRIN News, 2006a. 'Tanzania: AIDS Education as Rare as Tanzanite.' IRIN News, 4 July. Available at www.irinnews.org/report/39723/ tanzania-aids-education-as-rare-as-tanzanite

IRIN News, 2006b. 'Gem Slaves: Tanzanite's Child Labour.' IRIN News, 6 September. Available at www.irinnews.org/Report.aspx? ReportId $=61004$

Irish Boy, 2005. 'What the heck is Tanzanite!!' Cruise Critic, 14 November. Available at boards.cruisecritic.com/showthread.php?t=255939

Juma, M., 2008. 'Commission Hears Small-Scale Miners Grievances.' Arusha Times, Issue 501, 19-25 January. Viewed at www.arushatimes. co.tz/front_page_2.htm (site discontinued)

Kelsall, T., 2004. 'Contentious Politics, Local Governance, and the Self: A Tanzanian Case Study.' Nordiska Afrikaninstitutet, Research Report 129, Uppsala, Sweden. Available at nai.diva-portal.org/smash/record. jsf?pid=diva2 $\% 3 \mathrm{~A} 240552 \& \mathrm{~d}$ swid $=9561$

Kinabo, C., 2003. 'Women's Engagement and Child Labour in SmallScale Mining - Tanzanian Case Study.' Urban Health and Development Bulletin 6(4): 46-56.

Kondo, H., 2002. 'Minister Accuses AFGEM of Starting Tanzanite-al Qaeda Story.' Colored Stone, March/April 2002. Viewed at www.tucson showguide.com/stories/mar02/afgemnews.cfm (site discontinued)

Kondo, H., 2005. 'Tanzania Mining, Interrupted.' The Ganoksin Project, in association with Colored Stone, April 2005. Available at www. ganoksin.com/borisat/nenam/tanzania-mines.htm

Lange, S., 2006. 'Benefit Streams from Mining in Tanzania: Case Studies from Geira and Mererani.' CMI Report 2006: 11. Bergen: Chr. Michelsen Institute.

Maharaj, D., 2002. 'Gem Tied to Terror Loses Sparkle.' The Los Angeles Times, 20 March, p. A4.

Markon, J., 2002. 'Gemstone Dealers Named in Suit over Sept. 11.' The Wall Street Journal, 15 February, p. B1. 
McClure, M., 2003. 'Rhapsody of the Seas Cruise Review.' Available at www.cruisereviews.com/RoyalCaribbean/RhapsodyoftheSeas 58.htm

Mwakyusa, A., 2015. 'Tanzania: Kikwete Honours Brave Female TPDF Member.' Tanzania Daily News, 28 April. Available at allafrica.com/ stories/201504280246.html

Mwalyosi, R.B.B., 2004. 'Impact Assessment and the Mining Industry: Perspectives from Tanzania.' International Association of Impact Assessment Conference, April. Available at www.tzonline.org/pdf/ impactassessmentandtheminingindustry.pdf

Nakora, H., 2004. 'Game Meat Carnival Flourishes in Mererani.' Arusha Times, No. 333, 14-20 August. Viewed at www.arushatimes. co.tz/2004/32/local_news_5.htm (site discontinued)

Newman, J. 2007. 'Singing the Blues.' Robb Report, 1 May. Available at robbreport.com/Jewlery/Feature-Singing-the-Blues

Ngowi, H.P., 2001. 'Attracting New Foreign Direct Investments to Tanzania.' Tanzanet Journal 1(2): 23-39.

Nones, J., 2005. 'TanzaniteOne Unlocking the Riches of Mt. Kilimanjaro.' Resource Investor, 30 August. Viewed at www.resourceinvestor.com/ pebble.asp?relid=12517 (site discontinued)

Nyaumame, S., 2003. 'Drugs, Alcohol, Threaten Lives in Mererani.' Arusha Times, 19-25 July. Viewed at www.arushatimes.co.tz/.../ courts_\&_crime_1.htm (site discontinued)

Philemon, L., 2013. 'Small Miners ask Government to Reopen Mines.' IPP Media. Viewed at www.ippmedia.com/frontend/?1=57536 (site discontinued)

Philemon, L., 2015. 'Tanzanite Tourist Attraction Centre Launched in Arusha.' IPP Media. Viewed at www.ippmedia.com/frontend/index. php/ol\%3D23/javascript/page_home.js?l=79767 (site discontinued)

Polanyi, K., 1957 [1944]. The Great Transformation: The Political and Economic Origins of our Time. R. M. MacIver, ed. Boston: Beacon Press.

Roberts, C., 2002. 'Great Things to Do in St. Maarten: Shop.' Viewed at www.eaglelatitudes.com/current/article.html?id=7 (site discontinued) 
Roskin, G., 2002. 'At Tiffany, Tanzanite is Back in the Case.' Jewelers Circular Keystone, 1 September. Viewed at static.highbeam.com $/ \mathrm{j} /$ jewelerscircularkeystone/september012002/attiffanytanzaniteisback inthecasegemnotesbriefarti/ (site discontinued)

Rothery, M. and L. Rothery, 2004. 'Greetings from Tanzania.' Viewed at www.missionoz.com/NLet/June2004.htm (site discontinued)

Schroeder, R.A., 2010. 'Tanzanite as a Conflict Gem: Certifying a Secure Commodity Chain in Tanzania.' Geoforum 41: 56-65. doi. org/10.1016/j.geoforum.2009.02.005

Sheridan, M., 2005. Interview Notes. Personal communication to Katherine Donahue, April.

Tageo.com. 2012. 'Population, United Republic of Tanzania.' Available at www.tageo.com/index-e-tz-cities-TZ.htm

Tanzanite Foundation, n.d. 'Tanzanite and Tiffany.' Viewed at www.tan zanitefoundation.com/tanzanite_and_tiffany.html (site discontinued)

Tanzanite Gallery, 2007. 'Tanzanite: The Celebration of New Life.' Tanzanite History. Viewed at www.tanzanitegallery.com/acatalog/ Taznanite_History.html (site discontinued)

Tanzanite Gems, 2002. 'Update on Tanzanite.' Available at tanzanitegems. com/tanzanite2.php

TanzaniteOne, 2007. 'The Story.' Viewed at www.tanzaniteone.com/ tanzaniteone-tanzanite-story.asp (site discontinued)

TanzaniteOne, 2008. 'Maasai woman with baby.' Viewed at www. tanzaniteone.com/imagelibrary/19---Maasai-wearing-tanzani.jpg (site discontinued)

The Guardian/IPP Media, 2015. 'Govt Grapples to Turn Tanzanite Mining into New Tourism Destination.' 24 August. Available at en.africa time.com/tanzanie/articles/govt-grapples-turn-tanzanite-mining-newtourism-destination

Time, 1969. 'New and Hard to Come By.' Time Magazine, 24 January. Available at www.time.com/time/magazine/article/0,9171,900582,00. html?promoid=googlep 
United Nations Children's Fund (UNICEF), 2012. 'United Republic of Tanzania, Statistics.' Available at www.unicef.org/infobycountry/ tanzania_statistics.html

United Republic of Tanzania, 2002. 'Housing and Population Census.' Viewed at www.nbs.go.tz/Village_Statistics/PDF_files/Table _Manyara.pdf (site discontinued)

Weldon, R., 2002. 'Birth of a Birthstone.' Professional Jeweler Magazine Archives, December. Available at www.professionaljeweler.com/ archives/articles/2002/dec02/1202gn2.html

World Bank, 2014. 'Tanzania.' Available at data.worldbank.org/country/ tanzania 
This text is taken from Between the Plough and the Pick: Informal, artisanal and small-scale mining in the contemporary world, edited by Kuntala Lahiri-Dutt, published 2018 by ANU Press, The Australian National University, Canberra, Australia.

doi.org/10.22459/BPP.03.2018.03 